\title{
Physiognomic structure of agro-forestry landscapes: method of evaluation and guidelines for design, on the example of the West Polesie Biosphere Reserve
}

\author{
Tadeusz J. Chmielewski ${ }^{*}$, Agnieszka Kułak ${ }^{1}$,Malwina Michalik-Śnieżek ${ }^{1}$, and Bogdan Lorens ${ }^{2}$ \\ ${ }^{1}$ Department of Landscape Ecology and Nature Conservation, University of Life Sciences in Lublin, \\ Dobrzańskiego 37, 20-262 Lublin, Poland \\ ${ }^{2}$ Department of Geobotany, Maria Curie-Skłodowska University, Akademicka 19, 20-033 Lublin, Poland
}

Received January 21, 2016; accepted August 31, 2016

\begin{abstract}
A b s t r a c t. Harmonious planning of agro-forestry landscapes plays a increasing role in building a social satisfaction flowing from the high quality of the environment on the rural areas. It is also a very good way to create a unique place identity of protected areas, rest areas etc. especially valuable regions. The objectives of the paper are: 1) elaboration the method of evaluation and mapping the physiognomic landscape composition on the rural areas with a high natural values; 2) testing this method on dominated by forests, peatbogs and arable lands the central part of the West Polesie UNESCO Biosphere Reserve (Eastern Poland); 3) formulation of guidelines on the design of landscape interiors and view openings composition, highlighting the unique features of West Polesie landscape and building a sense of the place identity; 4) to show the necessary to enshrine the values of physiognomic landscape composition in land use policy. In evaluation and mapping the landscape composition, a special attention was paid to the role of agro-forest ecotones. The results of the research part of the study as well as a guidelines on landscape design have been presented in the form of a map, study figures and a description.

K e y w o r d s: agro-forestry landscape, landscape interiors, landscape gates, agro-forestry ecotones, West Polesie
\end{abstract}

\section{INTRODUCTION}

The Common Agricultural Policy after 2013 states that the main purposes of EU agriculture should be:

- provision of a safe, healthy choice of food, at transparent and affordable prices;

- ensuring sustainable use of the land;

- activities that sustain rural communities and the countryside;

- security of food supply (The Common Agricultural Policy after 2013).

\footnotetext{
*Corresponding author e-mail: tadeusz.chmielewski@up.lublin.pl
}

Simultaneously, the European Union Biodiversity Strategy (EUBS) (2011) states that landscape and ecosystems diversity in the EU is still decreasing and that most of ecosystems are seriously degraded by different anthropogenic pressures (including agriculture). Therefore this Strategy formulate a list of targets and actions needed to reverse those negative trends, especially to stop the loss of biodiversity and the degradation of ecosystem services by 2020 and at least a partial their restoration. Similar goals formulate also the document: Implementation of the Forest Europe Commitments (2015).

One of the greatest role in the European agro-forestry landscape diversity and connectivity conservation and development plays the European Landscape Convention. This convention obligate the Member States of the Council of Europe among others to:

- recognise landscapes in law as an essential component of people surroundings, an expression of the diversity of their shared cultural and natural heritage, and a foundation of their identity;

- establish and implement landscape policies aimed at landscape protection, management and planning;

- to establish procedures for the participation of the general public, local and regional authorities, and other parties with an interest in the definition and implementation of the landscape policies mentioned in above paragraph;

- to integrate landscape into its regional and town planning policies and in its cultural, environmental, agricultural, social and economic policies, as well as in any other policies with possible direct or indirect impact on landscape (European Landscape Convention, 2000).

(C) 2016 Institute of Agrophysics, Polish Academy of Sciences 
The main objective to develop the landscape policy is improving the quality of landscape, as natural and cultural heritage and the environment of life of present and future human generations. To achieve the high quality of the landscape, a skillfully combining of ecological, cultural, utilitarian and physiognomic (compositio-aesthetical) aspects should be provided.

The pattern of spatial distribution of forest and nonforest patches, their size and shape, character of borders, habitat types, species composition, etc. all these features have particular significance for the perception of landscape identity and the evaluation of its quality (Bell, 2012; Sevenant and Antrop, 2009). While the ecological role of inter-ecosystem borders (ecotones) has been well identified and described, the role of the composition of forest/ non forest landscape boundaries in shaping the physiognomic (aesthetic) values of a region has been the subject of increasing public interest only since the end of the 20th century (Eriksson et al., 2012; Karjalainen and Tyrväinen, 2002; Kohsaka and Flitner, 2004; Lamb and Purcell, 1990). Currently, there is growing emphasis on the ability to design forest-agricultural-settler landscape physiognomy is a key to building satisfaction derived from the high quality of the living environment (Nijnik and Mather, 2008; Tveit et al., 2006). It is also a way to create a unique place identity (Myczkowski, 2009).

The ecotone concept began as visually based stable delineations between distinct vegetation communities (Clements, 1905). Now, the ecotones are discussed in terms of ecological transitional zones: narrow, stochastic, unstable ecological stripes, possessing a mixture of two different homogenous community types. Inherent in the ecotone sharpness is its instability; although stable ecotones are possible, they are usually man made (Maarel, 1990). With the advent of landscape ecology, scientists started to use the term 'ecotone' to refer to the boundary enclosing a relatively homogenous landscape patch. In this landscape, view ecotones are still steep gradients between more homogenous patches of vegetation (Fortin et al., 2000; Risser, 1995), but these ecotones and the patches they surround can be viewed as landscape elements. Furthermore, ecotone research can be linked to landscape ecology topics such as edge penetration, edge effect, interior habitat, and ecological gradients (Ewers and Didham, 2006), as patches in fragmented landscape are spatially defined by their physical limits, or borders (Forman, 1995). Both biotic and abiotic properties of the patches are influenced by and subjected to spatial dynamics across these borders (Fernandez et al., 2002). Increasing fragmentation of landscape will also increase the importance of these dynamics within the created patches.

An anthropogenic ecotone separating a forest and a field is caused primarily by human disturbance. Secondarily, the change in species composition is caused by soil moisture differences, light gradients, microtopography, microclimate, and the movement of dispersal vectors. There may be eco- tonal species enjoying the unique edge environment. There may be additive blending of forest and field species (ie field species occurring in the forest and forest species occurring in the field, as a result of spatial mass effect). An opposing force is the possibility of high mortality if the ecotone represents a marginal environment for many species.

Among terrestrial systems, forest-grassland ecotones are among the most striking, dynamic, and widely studied. Globally, grass- and herb-dominated ecosystems are experiencing encroachment by woodlands and forests (Bowman et al., 2001; Coop and Givnish, 2008; Norman and Taylor, 2005) prompting concerns over the loss of biological diversity and potential of ecosystem services (Hoekstra et al., 2005; Van Auken, 2000).

Knowledge about ecological gradients and boundaries plays a significant role in the fields of phytosociology and landscape ecology, as well as nature conservation (Yarrow and Marin, 2007). Increased fragmentation due to human activity results in higher density of landscape boundaries (Pullin, 2002). These boundaries responses on global changes, especially on global climate change will probably be one of the most important research questions in the upcoming decades (Weltzin and McPherson, 2000).

As the basic spatial units used in the evaluation and design of physiognomic landscape composition, the landscape interiors are considered (Bogdanowski, 1976; Patoczka, 2000), sometimes referred also as landscape enclosures (Motloch, 2001).

Landscape interior (LI) is a fragment of an area surrounding the observer, which is distinguished from the environs by a proper composition of landforms and land cover. When the interior constitutes an element of a building, it is referred to as an architecture interior (AI); when it is part of an agriculture-settlement composition or a built-up area, it is called an architecture-landscape interior (ALI). In turn, an interior formed among natural ecosystems is defined as a nature-landscape interior (NLI) (Chmielewski, 2012).

A great number of various interiors can be distinguished in the landscape. In each, 4 basic types of composition elements can be identified:

- the base - constituting the foundations of the interior,

- the walls - delineating the interior boundaries,

- the canopy - closing and providing the interior with top lighting,

- freestanding elements ie complementary forms organising the detailed composition of the interior (Bogdanowski, 1976).

The base is represented by the floor inside a building, a pavement in the market square in a town, and crop fields together with roads, rivers, meadows, etc. in a natural-cultural landscape.

The interior walls in a building are formed by the walls of a room or hall, in a town by eg the frontage along a square, and in a natural-cultural landscape by forest ecotones, hill slopes, etc. 
The ceiling inside a building, canopy of tree branches in forest or garden, as well as the sky in the urban or naturalcultural landscapes constitute the canopy.

Freestanding elements are various forms present in the interior other than its walls or base. In a room, it could be eg a table, a pot plant; in the natural-cultural landscape a rock, a solitary tree, a shrubbery, a church, a group of houses, etc (Bogdanowski, 1976).

Between adjacent landscape interiors, there are vast scenic openings and narrow landscape gates (Patoczka, 2000), which visually link interior complexes, thus forming specific landscape sequences (Chmielewski and Kułak, 2014). Spatial interrelationships between these composition elements play an essential role in the perception of landscape quality (Nijnik et al., 2008).

Currently, a vast majority of terrestrial landscapes managed by man represent diverse compositions of forest, agricultural, and settlement areas. A dominant role in this spatial structure is ascribed to architecture-landscape interiors, whose walls are formed by forest ecotones and peripheries of built-up areas and whose bases consist of arable land, waters, and natural non-forest ecosystems (Chmielewski, 2012). Therefore, the spatial pattern of land use patches as well as the shape and character of landscape ecotones largely contribute to the physiognomic attractiveness of a region (Bell, 2001).

Detailed knowledge about the spatial composition and physiognomic landscape diversity in the system of agro-forest ecotones is fundamental for conservation and design of landscape aesthetic values, style, and identity. Particularly valuable nature and landscape areas, primarily UNESCO Biosphere Reserves, are regions where these ideas and principles should be developed and implemented in the first place.

The objectives of the paper are:

- elaboration the method of evaluation and mapping the physiognomic landscape composition on the rural areas with a high natural values;

- testing this method on dominated by forests, peatbogs and arable lands the central part of the West Polesie UNESCO Biosphere Reserve (Eastern Poland);

- formulation of guidelines on the design of landscape interiors and view openings composition, highlighting the unique features of West Polesie landscape and building a sense of the place identity;

- to show the necessary to enshrine the values of physiognomic landscape composition in land use policy.

\section{STUDY AREA}

The Polesie is one of the largest structural units in Eastern Europe, known as physiographic subprovinces. It stretches from east to west over approximately $700 \times 300 \mathrm{~km}$. The western border of the subprovince Polesie is based on the first order of physiographic boundary, separating Eastern and Western Europe. In the south and south-west, the
Polesie is adjacent to the physiographic border of European highlands and old mountains zone (Kondracki, 1998). In the biogeographical aspect, the Polesie is located inside the biome of deciduous forest of the moderate climatic zone (continental biogeographic region). In the north, it is adjacent to the biome of coniferous forests, in the province of sub-taiga (boreal biogeographic region) (Biogeographic Regions in Europe, 2015). This subprovince is the largest complex of wetland ecosystems (including wet forests) in Europe, with an extremely important role in protection of water resources, stabilisation of climate conditions, and biodiversity conservation in the continent (Chmielewski, 2005).

In this particular place of Europe, the 'West Polesie' Transboundary Biosphere Reserve (WP TBR) is located: the western edge of the subprovince Polesie, at the crossroads of contrasting physiographic and biogeographic macrostructures, on the eastern edge of the European Union, and in the adjoining zone of the borders of three countries: Belarus, Poland, and Ukraine (Fig. 1). It was created in 2012 on an area of 263016 ha.

A characteristic feature of the WP TBR is very flat terrain, covered with a mosaic of forests, bogs, meadows and fields, among which numerous lakes and diverse wetlands of great biological diversity are located. The West Polesie TBR plays a crucial role as a juncture of different biogeographic elements, migration pathways, and cultural landscapes (Chmielewski, 2005).

The most valuable natural central region of the Polish part of the WP TBR with the Polesie National Park established in 1990 (Radwan, 2002), was chosen as a study area (Fig. 1).

Three zones were distinguished in the spatial structure of the study area: A - the area of the Polesie National Park (9764 ha) composed of 2 parts: (A1) the main complex and (A2) the Bagno Bubnów - Bagno Staw complex; B - an area of the buffer zone of the National Park (14 042 ha); C - the so-called landscape context zone (7 908 ha), ie a strip of land with a maximum width of $4.5 \mathrm{~km}$ surrounding and linking both parts of the park into a functional unity (Table 1).

\section{MATERIALS AND METHODS}

The first stage of the work involved classification of the study area into a system of basic landscape units (BLU). These units were delimited in accordance with the method described by Zonneveld (1989) and developed by Chmielewski $(2006,2012)$. The source materials included 1:25000 geological, geomorphological, pedological, hydrographic, and geochemical maps, an actual vegetation map, and a map of land use structure, which were developed for the first edition of the Nature Conservation Plan for the Polesie National Park in 1997-1999 (Radwan, 1999). The results of this stage of the study were published in a separate article (Chmielewski, 2006). In 2014, the results were 


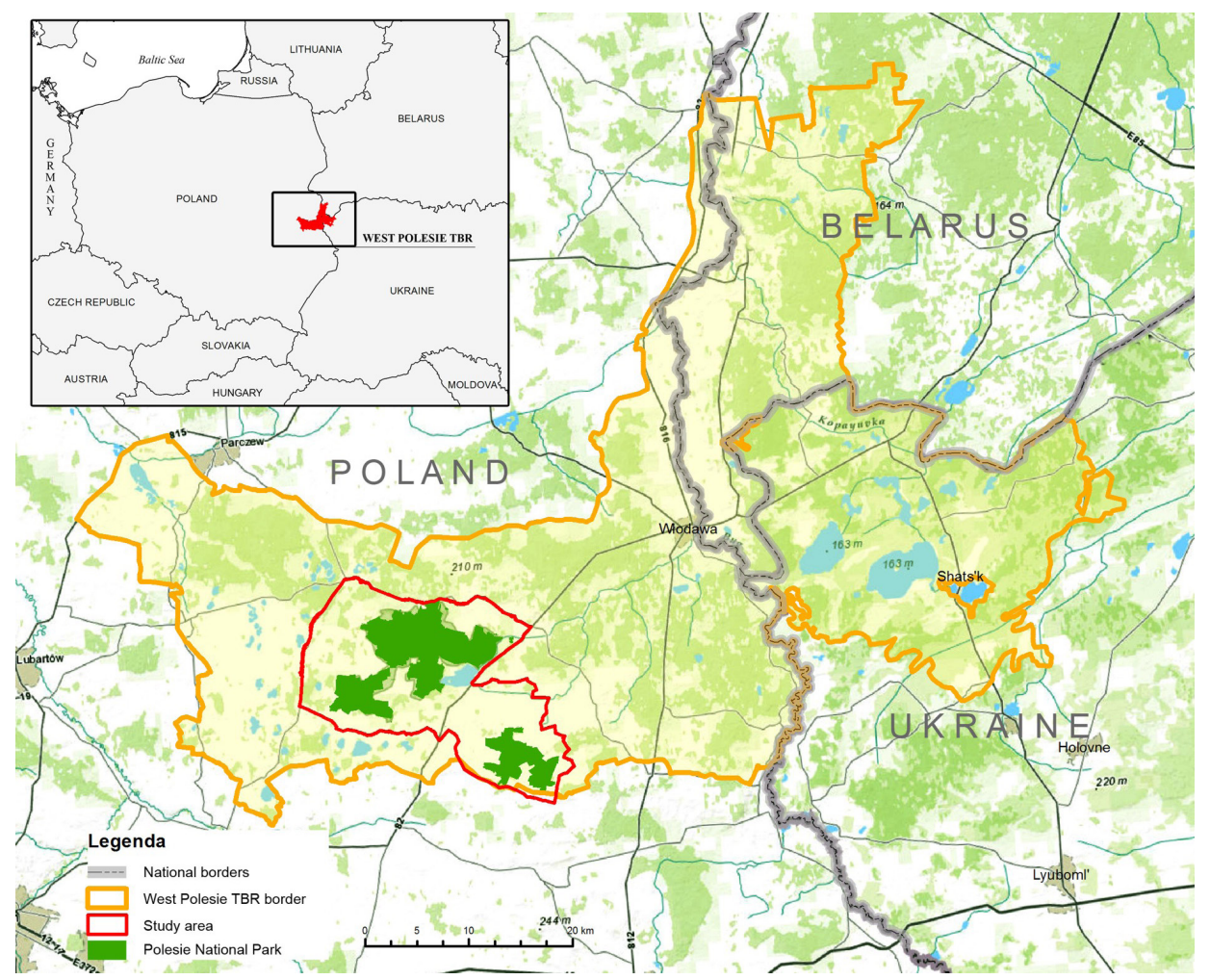

Fig. 1. Location of the study area.

T a b l e 1. Land use structure of the Polesie National Park functional area

\begin{tabular}{|c|c|c|c|c|c|c|c|c|}
\hline \multirow{2}{*}{$\begin{array}{l}\text { Types } \\
\text { of land use }\end{array}$} & \multicolumn{2}{|c|}{ PNP } & \multicolumn{2}{|c|}{ Buffer zone of PNP } & \multicolumn{2}{|c|}{$\begin{array}{c}\text { Zone of 'landscape } \\
\text { context' area }\end{array}$} & \multicolumn{2}{|c|}{ Total study area } \\
\hline & (ha) & $(\%)$ & (ha) & $(\%)$ & (ha) & $(\%)$ & (ha) & $(\%)$ \\
\hline Water & 876.95 & 9.0 & 794.4 & 5.7 & 56.58 & 0.7 & 1727.93 & 5.4 \\
\hline Peatlands & 1478.63 & 15.1 & 208.4 & 1.5 & 19.46 & 0.2 & 1706.49 & 5.4 \\
\hline Wet shrubs & 203.79 & 2.1 & 119.84 & 0.9 & 94.6 & 1.2 & 418.23 & 1.3 \\
\hline Forests & 5114.35 & 52.4 & 3533.39 & 25.2 & 1617.4 & 20.5 & 10265.14 & 32.4 \\
\hline Meadows & 696.18 & 7.1 & 3405.41 & 24.3 & 3275.85 & 41.4 & 7377.44 & 23.3 \\
\hline $\begin{array}{l}\text { Dry grasslands } \\
\text { and heaths }\end{array}$ & 1133.94 & 11.6 & 953.57 & 6.8 & 394.12 & 5.0 & 2481.63 & 7.8 \\
\hline Farmlands & 240.15 & 2.5 & 4548.63 & 32.4 & 2091.31 & 26.4 & 6880.09 & 21.7 \\
\hline Built-up areas & 20.01 & 0.2 & 478.36 & 3.4 & 358.68 & 4.5 & 857.05 & 2.7 \\
\hline Total & 9764 & 100.0 & 14042 & 100.0 & 7908 & 100.0 & 31714 & 100.0 \\
\hline
\end{tabular}

verified using a digital terrain model and an orthophotomap from 2012 with a pixel terrain resolution of $0.25 \mathrm{~m}$, including one additional criterion, ie features of landscape physiognomy (Weigle, 2014).

Next, based on the analysis of the orthophotomap, individual BLUs were classified in terms of their physiognomic landscape types. In accordance with the classification developed by Chmielewski and Kułak (2014), the basic cri- teria for identification of the physiognomic landscape types comprised: (a) types of landform and (b) patterns of land cover texture. Since the entire area analysed is extremely flat, the former criterion was not a differentiating factor.

Based on the latter criterion, 7 types of land cover textures were distinguished in the study area: (1) open; (2) fenced; (3) inlaid; (4) mosaic; (5) labyrinthine; (6) perforated; and (7) covered landscape. The open landscape type 
T a b I e 2. Classification of the BLU physiognomic landscape types, identified on the basis of the pattern of land cover structure and texture

\begin{tabular}{lc}
\hline Pattern of land cover texture & $\begin{array}{c}\text { Share (\%) of forest, trees and } \\
\text { built-up areas in the LI area }\end{array}$ \\
\hline Open lanscape & $<1$ \\
Fenced landscape & $1-25$ \\
Inlaid landscape & $1-25$ \\
Mosaic landscape & $25.1-50$ \\
Labyrinthine landscape & $50.1-75$ \\
Perforated landscape & $75.1-90$ \\
Covered landscape & $>90$ \\
\hline
\end{tabular}

included areas of waters, bogs, meadows, grasslands, and fields. When the open space of the BLU was divided into geometrical landscape interiors by a hedgerow network, such an area was defined as a fenced landscape. When the texture of the open landscape was enriched with solitary trees and buildings, scattered groups of trees, shrubs, or buildings, and possibly isolated scrub patches or small forest patches covering up to $25 \%$ of the total BLU area, the areas were defined as inlaid landscapes. When these forms of land cover occupied from 25.1 to $50 \%$ of the zone surface, the areas were assigned to the mosaic landscape type. At a value reaching $50.1-75 \%$, the land was defined as labyrinthine landscape zones. At values of $75.1-90 \%$, the area was classified as a perforated landscape zone. Above $90 \%$, the term 'covered landscapes' was used (Table 2).

The second stage of the work consisted in field studies. In 2014, during a series of field route walks with the use of an orthophotomap and a GPS receiver in accordance with the methodology proposed by Chmielewski and Kułak (2014), we identified: (a) a system of landscape interiors; (b) scenic openings and landscape gates representing gaps in the landscape interior walls; and (c) viewpoints in the structure of individual BLUs and their complexes.

Enclaves of open landscapes (waters, bogs, meadows, grasslands, fields) with an area between 1 ha and 200 ha surrounded by forest patches, densely built-up areas or separated by hedgerows were regarded to be landscape interiors (Smaller spaces are regarded as landscape microinteriors. Due to the large size of the analysed area and the cartographic scale, this level of landscape arrangement was not investigated in this study). Such structures were mainly found in BLUs with perforated and labyrinthine landscapes and in units with fenced landscapes. When the open areas had a form of a uniform complex covering an area greater than 200 ha with very distant and hardly visible forest walls, such spatial arrangements were referred to as open landscape zones.
Gaps in the walls of landscape interiors with a width over $100 \mathrm{~m}$ were defined as scenic openings; those with a width of 10-100 m were referred to as (landscape gates) (smaller gaps are referred to as landscape windows or openwork sections of landscape walls; this level of landscape organisation is not the object of the study presented in this article).

Sites, wherefrom it was possible to observe open or inlaid landscape zones (entire or a larger part thereof) or a complex of a few landscape interiors were referred to as viewpoints.

All these elements of landscape composition were marked on the orthophotomap. Notes were made about the physiognomic characteristics of the individual mapped areas, in particular concerning the type of the interior base, the character of the interior walls (forest, shrubby-forest, mosaic, urbanised, hedgerow network), the dynamics of the interior walls (during the succession/regressive/stabilised by man), and the character and spatial arrangement of landscape inlays, etc.

An important element of the field studies was the analysis of the physiognomic composition of selected landscape interiors surrounded by forests. In accordance with the methodology designed by Bogdanowski (1976) and further developed by Chmielewski et al. (2014), the implementation of this task involved: (1) taking a panoramic photograph of the analysed landscape interior; (2) preparation (using a graphic tablet) of a sketch of the main composition elements of the interior and evaluation of its role and values; (3) development of guidelines on conservation and management of the landscape.

The third stage of the investigations consisted in final analysis of results and: (1) development of the concept of the Landscape Interior Card; (2) formulation of guidelines on the composition of landscape interiors and design of view openings, highlighting the unique features of Polesie landscape.

\section{RESULTS}

In the study area, 198 BLUs were established (Fig. 2). Their surface area ranged from 4.7 ha to 2358.2 ha, with an average value of 142.8 ha. In all the analysed set, very small and small units (with an area below 100 ha) were the most numerous (97). Although their number accounted for nearly $49 \%$ of the analysed set, they covered only $14.1 \%$ of the total surface of the study area. The greatest area was occupied by the largest units, ie 21 units accounted for $35.7 \%$ of the study area (Table 3 ). This result is highly influenced by the area of the largest unit 'Krowie Bagno' (2358.2 ha).

The classification of BLUs in terms of their physiognomic landscape types reveals that the greatest surface area is occupied by units with open landscape (26.01\%); the second place is taken by units representing mosaic 


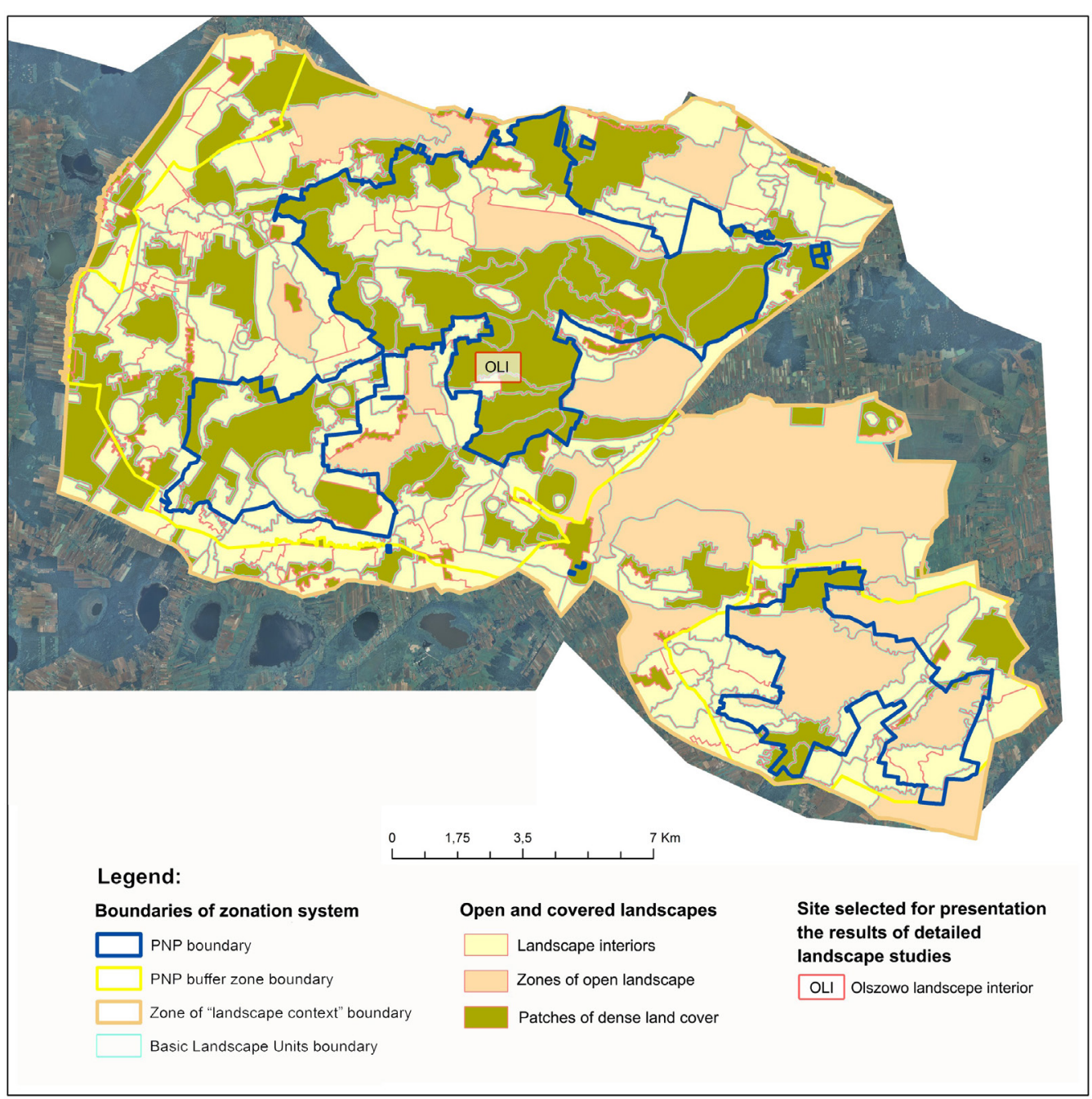

Fig. 2. Open and covered landscapes in the Polesie National Park functional area, on the background of the borders of basic landscape units (BLU).

T a b l e 3. Number and size of the BLU delimited on the study area

\begin{tabular}{cccc}
\hline $\begin{array}{c}\text { Size range } \\
\text { (ha) }\end{array}$ & $\begin{array}{c}\text { Number } \\
\text { of BLU }\end{array}$ & $\begin{array}{c}\text { Area } \\
\text { (ha) }\end{array}$ & $\begin{array}{c}\text { Share in total surface } \\
\text { of study area (\%) }\end{array}$ \\
\hline$<50$ & 52 & 1242.1 & 3.9 \\
$50-100$ & 45 & 3223.0 & 10.2 \\
$100.1-150$ & 31 & 3329.3 & 10.5 \\
$150.1-200$ & 22 & 5186.0 & 16.4 \\
$200.1-250$ & 11 & 2389.4 & 7.5 \\
$250.1-300$ & 6 & 1684.7 & 5.3 \\
$300.1-350$ & 8 & 2602.8 & 8.2 \\
$350.1-400$ & 2 & 745.3 & 2.3 \\
$>400$ & 21 & 11311.5 & 35.7 \\
Total & 198 & 31714.0 & 100.0 \\
\hline
\end{tabular}

landscape $(25.05 \%)$ and the third by units with perforated landscape (15.24\%). These data indicate high diversity of the landscape texture in the study area and suggest presence of numerous landscape interiors, openings, and gates.

However, the share of perforated and covered landscapes in the Polesie National Park is substantially higher, which is related to the considerable forest cover in this area. In the BLU complex located within the PNP, the greatest area is occupied by the following types: perforated landscapes $(30.88 \%)$, covered landscapes [dense forest complexes] (20.21\%), and open landscapes (18.07\%).

In the National Park, the share of labyrinthine landscapes is the highest from the 3 analysed zones $(11.56 \%)$, which implies intense processes of natural succession of forest and scrub communities and an increasing degree of the landscape naturalness. The lowest share in the PNP area is exhibited by fenced landscapes $(3.41 \%)$. They are located in areas of previous (until the $60 \mathrm{~s}$ of the 20 th century) naturally valuable open peatbogs dissected by a network of drainage ditches, drained, and turned into meadows in the $60 \mathrm{~s}$ and $70 \mathrm{~s}$ of the 20th century (before the establishment of the PNP) and later incorporated into the National 
T a b l e 4. Open and covered landscapes in the Polesie National Park functional area

\begin{tabular}{|c|c|c|c|c|c|c|c|c|}
\hline \multirow{2}{*}{ Landscape types } & \multicolumn{2}{|c|}{ PNP } & \multicolumn{2}{|c|}{ Buffer zone of PNP } & \multicolumn{2}{|c|}{$\begin{array}{c}\text { Zone of 'landscape } \\
\text { context' area }\end{array}$} & \multicolumn{2}{|c|}{ Total study area } \\
\hline & (ha) & $(\%)$ & (ha) & $(\%)$ & (ha) & $(\%)$ & (ha) & $(\%)$ \\
\hline Lanscape interiors & 3052.94 & 30.41 & 7542.61 & 54.42 & 2624.49 & 33.58 & 13220.04 & 41.69 \\
\hline Zones of open landscape & 1543.18 & 15.37 & 3019.18 & 21.79 & 3462.23 & 44.29 & 8024.59 & 25.30 \\
\hline Patches of dense land cover & 5443.44 & 54.23 & 3296.58 & 23.79 & 1729.35 & 22.13 & 10469.37 & 33.01 \\
\hline Total & $10039.56^{*}$ & 100.00 & $13858.37^{*}$ & 100.00 & $7816.07 *$ & 100.00 & 31714.00 & 100.00 \\
\hline
\end{tabular}

*The surfaces of open and covered areas in tested BLUs clusters are not identical to the surfaces of the individual 3 functional zones (see Table 1), because the administrative boundaries of the national park and its protective zone in some places are not compatible with the borders of BLU. Landscape units crossed by the administrative border of the PNP were included to the area of the PNP, if more than $50 \%$ of their surface was inside the park. Analogous was the procedure in the case of BLU located in the protection zone of PNP.

T a b l e 5. Types of interior walls identified in the Polesie National Park functional area

\begin{tabular}{|c|c|c|c|c|c|c|c|c|}
\hline \multirow{2}{*}{ Type of interior wall } & \multicolumn{2}{|c|}{ PNP } & \multicolumn{2}{|c|}{ Buffer zone of PNP } & \multicolumn{2}{|c|}{$\begin{array}{l}\text { Zone of 'landscape } \\
\text { context' area }\end{array}$} & \multicolumn{2}{|c|}{ Total study area } \\
\hline & $(\mathrm{km})$ & $(\%)$ & $(\mathrm{km})$ & $(\%)$ & $(\mathrm{km})$ & $(\%)$ & $(\mathrm{km})$ & $(\%)$ \\
\hline Forest & 109.82 & 49.31 & 217.90 & 48.680 & 72.08 & 35.70 & 399.80 & 45.84 \\
\hline Shrubby-forest & 69.01 & 30.99 & 37.40 & 8.355 & 17.86 & 8.84 & 124.27 & 14.25 \\
\hline Mosaic & 32.15 & 14.44 & 106.66 & 23.830 & 41.63 & 20.62 & 180.44 & 20.68 \\
\hline $\begin{array}{l}\text { Urbanized (the periphery of } \\
\text { settlements) }\end{array}$ & 0.19 & 0.09 & 57.54 & 12.855 & 37.1 & 18.38 & 94.83 & 10.87 \\
\hline Hedgerow network & 11.52 & 5.17 & 28.12 & 6.280 & 33.23 & 16.46 & 72.87 & 8.36 \\
\hline Total & 222.71 & 100.00 & 447.6 & 100.00 & 201.9 & 100.00 & 872.21 & 100.00 \\
\hline
\end{tabular}

Park. During the following 3 decades, belts of trees and shrubs grew by natural succession along these unmanaged ditches, forming the characteristic landscape with a hedgerow network. As a result of numerous projects of active nature conservation and landscape design undertaken by the PNP services, the landscapes are gradually becoming more similar to natural areas.

The highest share in the buffer zone is exhibited by mosaic landscapes $(42.78 \%)$ followed by open landscape $(24.56 \%)$. The same two forms, although in different proportions, predominate in the 'zone of the landscape context'. This is associated with the dominant role of agriculture in both these zones.

In the physiognomic structure of the whole BLU system, 230 landscape interiors, 11 zones of open landscape, and 112 patches of dense land cover were identified (Fig. 2). The total area of the interiors is 13220,04 ha; zones of open landscape cover 8024.59 ha, and the area of the patches of dense land cover separating them is 10469.37 ha (Table 4). The minimum area of the lands- cape interior is 1.05 ha and the maximum value reaches 198.91 ha. A minimum area regarded as a patch of dense land cover is 1.0 ha, a maximum attain 515.08 ha.

In the area of the PNP, there are fewer landscape interiors and open landscape zones than in the other two zones. Park is dominated $(54.23 \%)$ by patches of dense land cover (Table 4), almost exclusively constituted by forests.

The total length of the interior walls in the entire analysed set of landscape interiors is $222.71 \mathrm{~km}$. The highest proportion is represented by forest walls $(45.84 \%)$; the second place is held by mosaic-structure walls $(20.68 \%)$, and the third by shrubby-forest walls (14.25\%). The share of forest walls and shrubby-forest walls in the Polesie National Park is higher, ie 49.31 and $30.99 \%$, respectively. Urbanised walls (the periphery of settlements) account for $10.87 \%$ of the total length of all landscape interior walls, but their share in the PNP is only $0.19 \%$. Hedgerow network walls represent $8.36 \%$ of the total length of the landscape interior walls; however, their share in the PNP is lower, ie 5.7\% (Table 5). 
T a b l e 6. Structure of ecotones identified in the Polesie National Park functional area

\begin{tabular}{|c|c|c|c|c|c|c|c|c|}
\hline \multirow{2}{*}{ Structure of ecotones } & \multicolumn{2}{|c|}{ PNP } & \multicolumn{2}{|c|}{ Buffer zone of PNP } & \multicolumn{2}{|c|}{$\begin{array}{c}\text { Zone of 'landscape } \\
\text { context' area }\end{array}$} & \multicolumn{2}{|c|}{ Total study area } \\
\hline & $(\mathrm{km})$ & $(\%)$ & $(\mathrm{km})$ & $(\%)$ & $(\mathrm{km})$ & $(\%)$ & $(\mathrm{km})$ & $(\%)$ \\
\hline Broad, mild gradient & 57.39 & 25.77 & 64.12 & 14.33 & 29.16 & 14.44 & 150.67 & 17.27 \\
\hline Broad labirynthine & 100.74 & 45.23 & 117.84 & 26.33 & 22.34 & 11.07 & 240.92 & 27.62 \\
\hline Terrace & 21.90 & 9.83 & 19.58 & 4.37 & 1.11 & 0.55 & 42.59 & 4.88 \\
\hline Linear & 42.68 & 19.17 & 246.06 & 54.97 & 149.28 & 73.94 & 438.02 & 50.23 \\
\hline Total & 222.71 & 100.00 & 447.6 & 100.00 & 201.9 & 100.00 & 872.21 & 100.00 \\
\hline
\end{tabular}

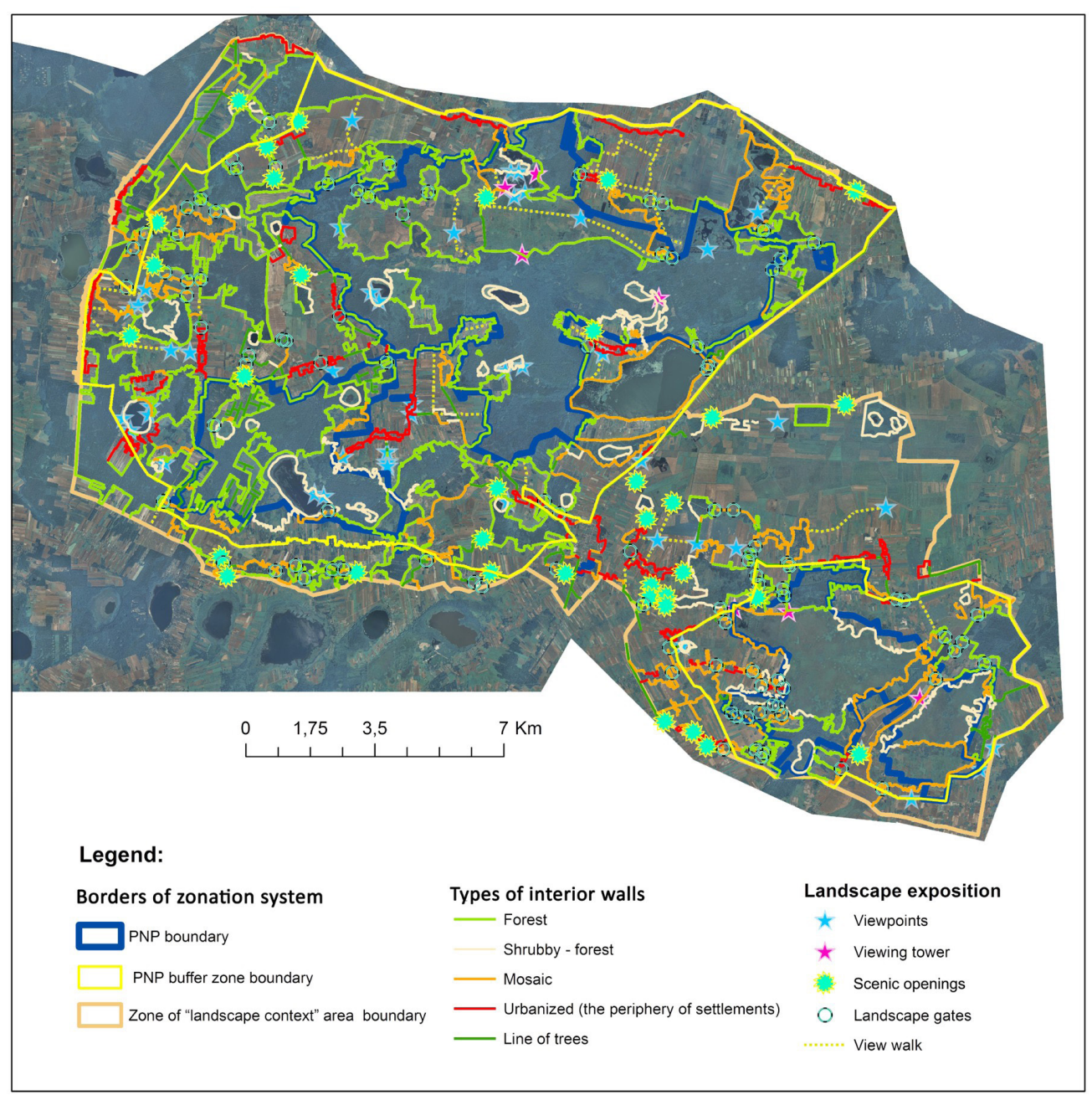

Fig. 3. Characteristics of landscape interior walls and location of landscape gates and scenic openings in the study area.

Linear ecotones with a structure shaped by human activity have the highest share (50.23\%) in the study area; yet, broad labyrinthine ecotones, which contribute to the considerable degree of naturalness of the assessed landscapes, have a substantial share $(27.62 \%)$. In the PNP, this type of ecotones plays a dominant role in the landscape (Table 6).
During field studies, 43 viewpoints, 33 scenic openings, and 81 landscape gates were identified in the study area. A majority of these particular places are located in the surroundings of the National Park and on the banks of lakes, ponds, and peatbogs inside the Park (Fig. 3). 
Obviously, this is not a complete inventory, since identification of this type of sites is subjective and the result of the field study is dependent on such factors as the length of the traversed routes, number of explored sites, terrain availability, season of the year (the degree of vegetation cover development), etc. In especially attractive scenic sites of the PNP area, the park service staff built 7 viewing towers for tourist and educational purposes, which are now the most popular and most visited sites.

The results of more detailed analyses of the physiognomic composition and dynamics of landscape interior walls, was presented on the example of a mid-forest landscape interior in sacred spot Olszowo (its location - vide Fig. 2).

Sacred spot Olszowo is located in the central part of the Polesie National Park, within an area covered by a wetland restoration project. Before the $60 \mathrm{~s}$ of the 20th century, in the area there were backwater reservoirs and stagnant water bodies, bog-birch communities (Betuletum pubescentis), bog pine forest (Vaccinio uliginosi-Pinetum), and alder peat-bog forest (Sphagno squarrosi-Alnetum) (Chmielewski, 2009). During the next two decades, the habitats were drained and the natural forest communities were replaced by commercial forests.
After establishment of the Polesie National Park (1990), the implementation of the wetland restoration project was initiated and it is being carried out at present. It has resulted in restoration of a substantial part of mid-forest water reservoirs and initiation of the process of regeneration of marshy and wetland forest habitats. The analysis of the composition of the landscape interior emerging in the area covered by the project shows that a vast majority of the ecotones contained in the interior walls has a broad labyrinthine or mild gradient, regressive character (Figs 4 and 5a).

The analysis and assessment of the physiognomic and educational values of this interior allowed formulation of guidelines on continuation of the work aiming at nature conservation and landscape design (Fig. 5b-d).

In order to systematise the method for recording the entire series of analyses of local or regional clusters of landscape interior composition, an idea of presentation thereof as a Landscape Interior Cards catalogue was developed. Figure 6 presents a pattern of such a card.

The Card consists of 4 parts: (1) Regional study and historical analysis (historical analyses were not performed during the study presented in this article, but they are an important element of many landscape studies);

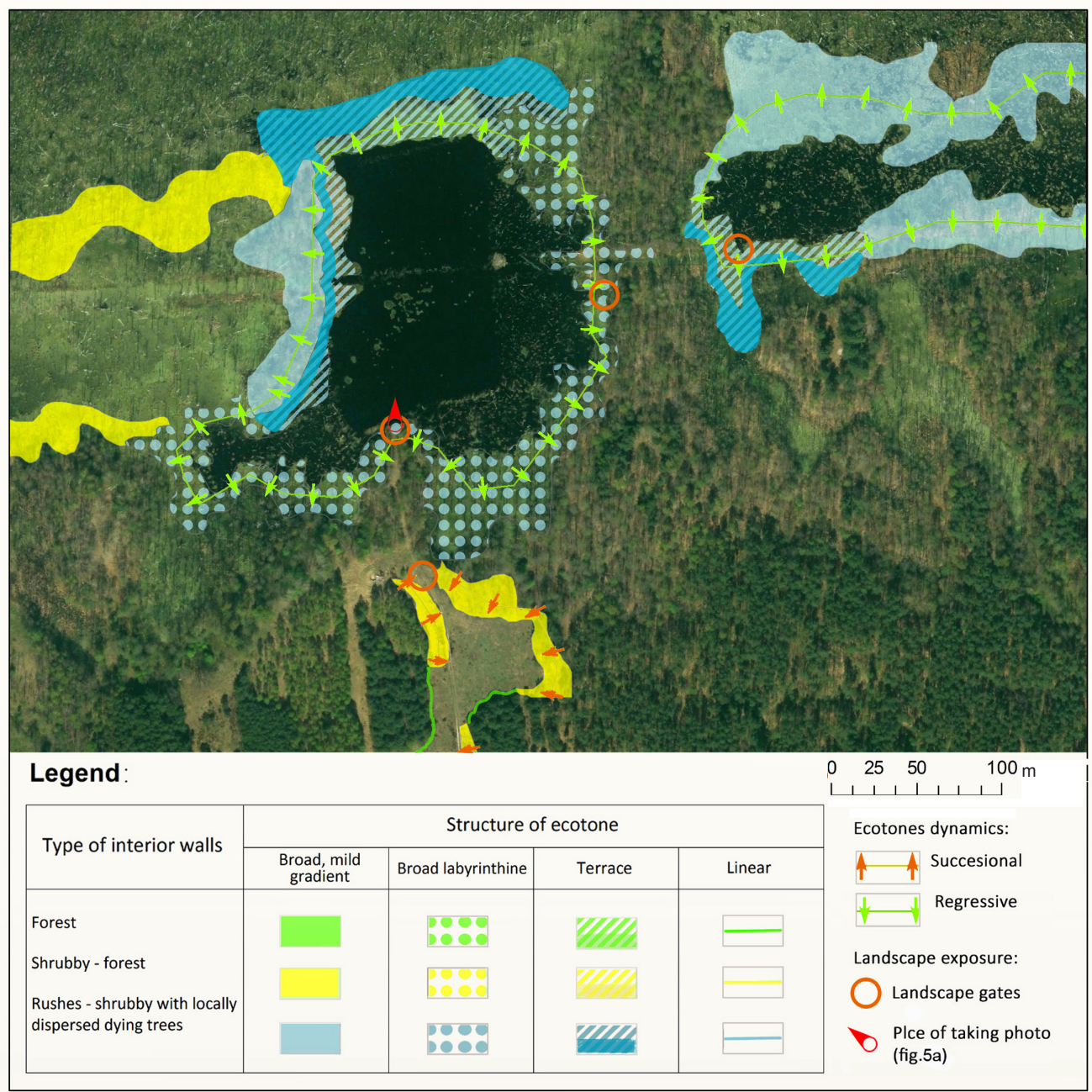

Fig. 4. Analysis of the composition and dynamics of the walls of the landscape interior in the sacred spot Olszowo. 

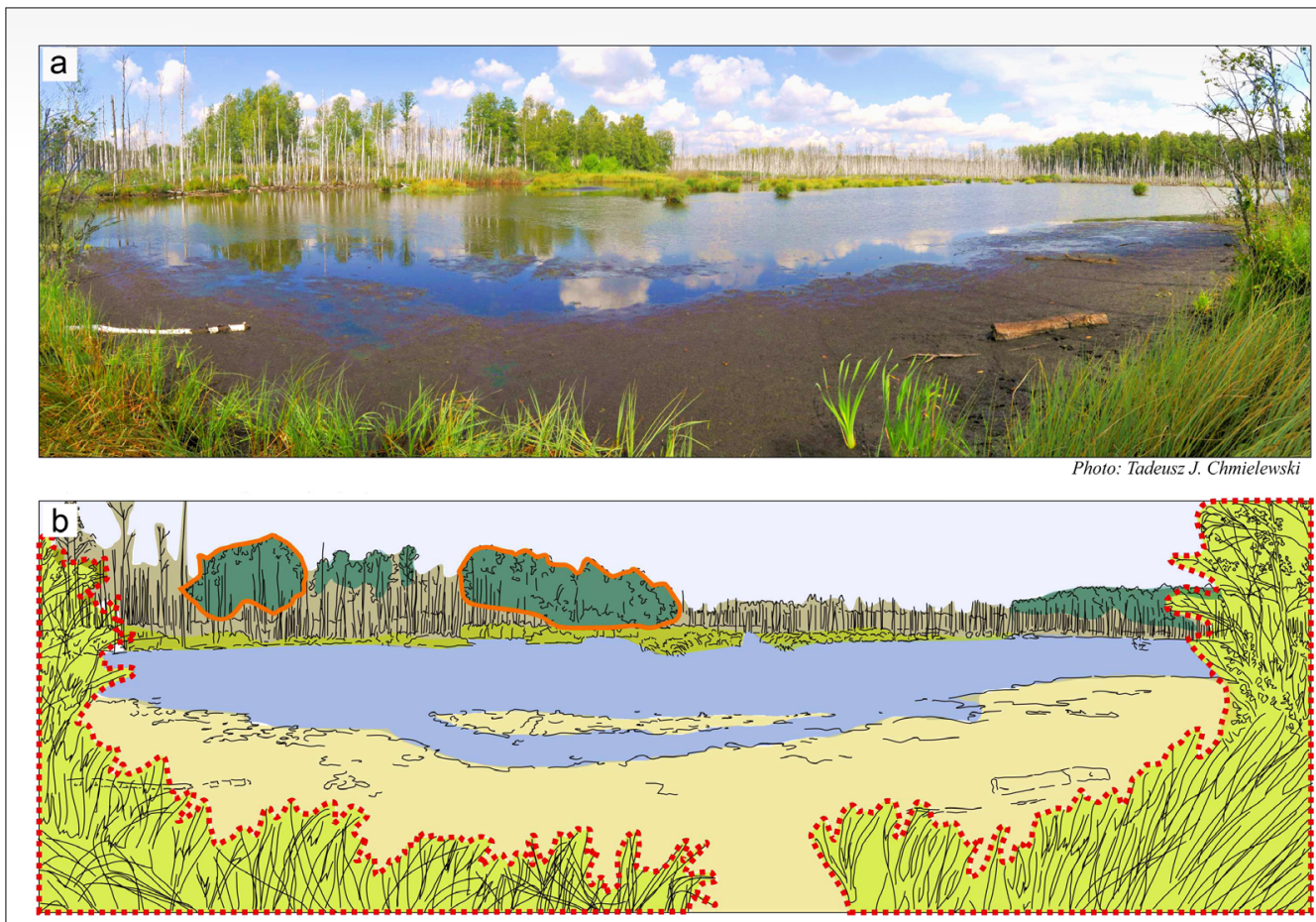

Baseground: $\square$ grassy - shrubby $\square$ peaty $\square$ open water Walls: $\square$ concrete $\square$ clerances (dying trees) Main composition elements: $\because$ landscape gate $\rightleftharpoons$ composition group Canopy:

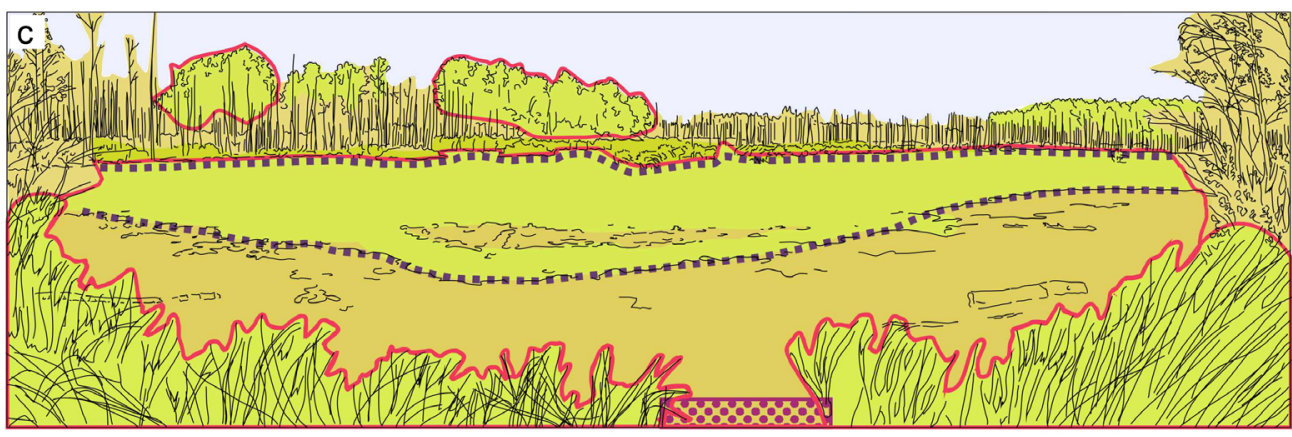

Evaluation - elements: $\square$ positive - creating place identity $\square$ positive - creating place naturality $\square$ neutral Guidelines - elements to: $\ldots$ incerase and stabilize water level $\longleftarrow$ increase of biodiversity

Dod introducing an element of educational development

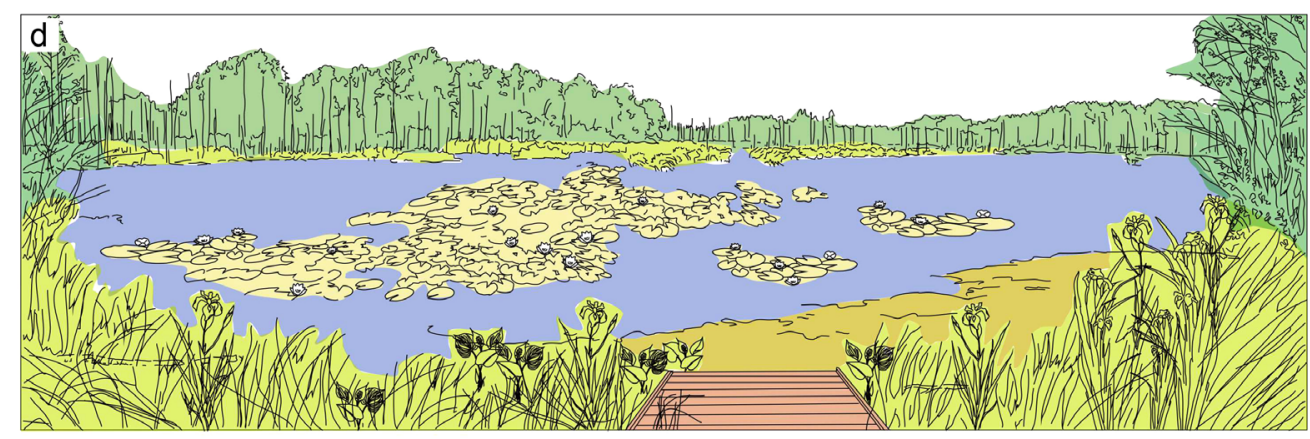

Designed $\square$ open water $\square$ peaty baseground $\square$ nympheides patches $\square$ species enriched rushes zone elements: $\square$ species enriched forest zone $\square$ educational - viev platform

Fig. 5. Study of Olszowo interior composition: $a$ - panoramic photography; b - identification of the main elements, $\mathrm{c}$ - evaluation of the main elements and guidelines for its design, $\mathrm{d}$ - project of Olszowo interior design. 

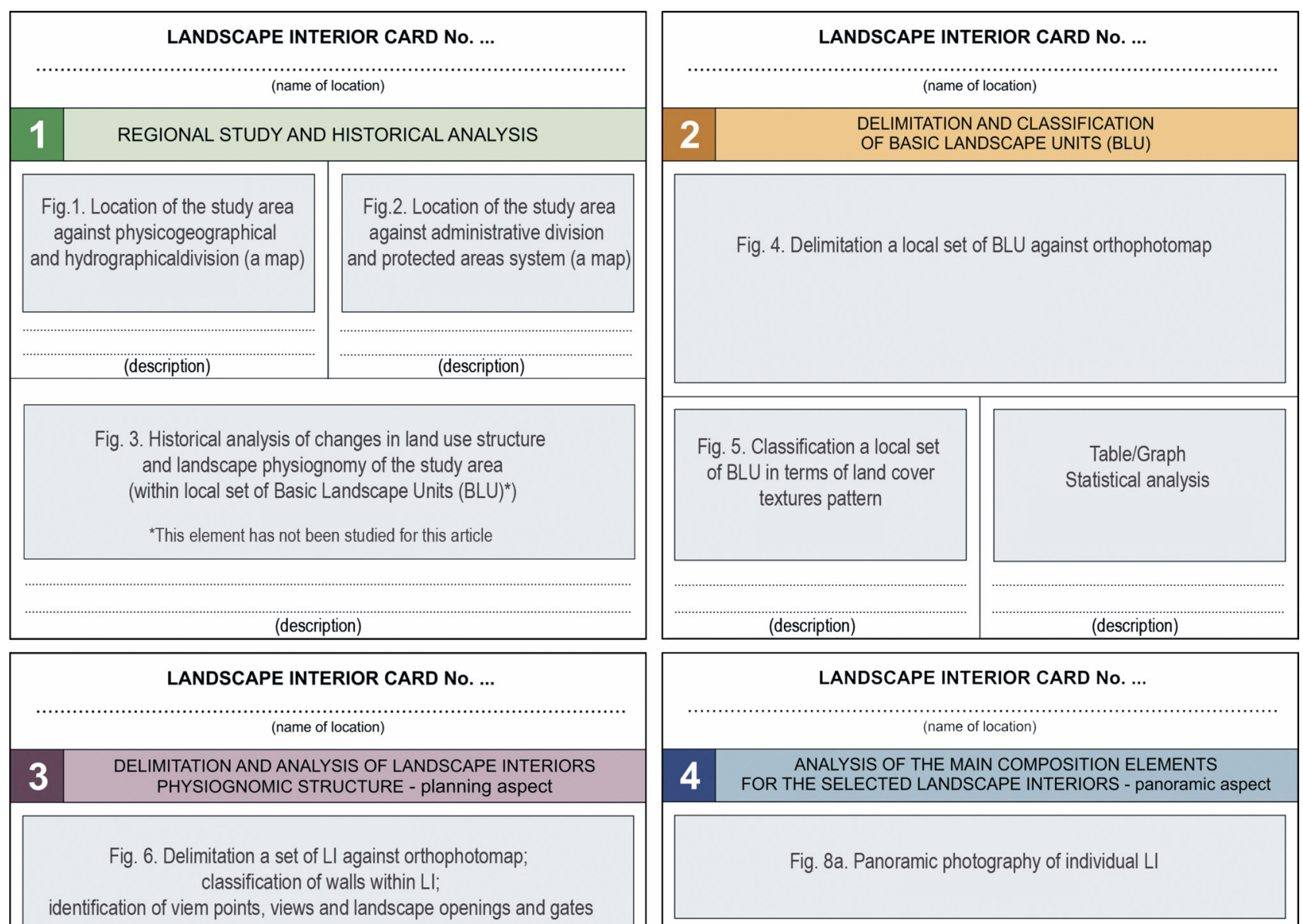

Fig. 6. Delimitation a set of $\mathrm{LI}$ against orthophotomap; classification of walls within LI; identification of viem points, views and landscape openings and gates against orthophotomap and local set of BLU

Fig. 8b. Simplified ilustration - identification of the main elements of composition for individual $\mathrm{LI}$

\section{(description)}

Fig. 7. The analysis of composition and dynamics of the walls and the base* against approximation of orthophotomap

*This base dynamics has not been studied for this article

Fig. 6. Template of the Landscape Interior Card. 
(2) Delimitation and classification of basic landscape units (BLU); (3) Delimitation and analysis of the physiognomic structure of landscape interiors (LI) - a planning aspect; (4) Analysis of the main composition elements of selected LI - a panoramic aspect.

A set of such Cards developed for a single BLU or a local BLU complex can constitute a Landscape Catalogue for a region.

The landscape studies supported by previously collected data on the ecology of the West Polesie landscape (Chmielewski, 2009) allowed formulation of 10 general guidelines on landscape conservation and design in the central part of the West Polesie Biosphere Reserve:

1. Conservation and design of the characteristic 'Polesie' landscape style, manifested by a naturalistic mosaic of forest, peatbog, and aquatic ecosystems as well as a cultural mosaic of fields, meadows, and trees; diversification of the structure and texture of the open landscape zones; conservation of the system of diverse landscape interiors as well as accompanying panoramas and scenic openings with special attention placed on the diversity of the structure of forest, peatbog, and aquatic ecotones; preservation of traditional spatial patterns of villages, conservation and promotion of regional architecture and the strip arrangement of fields.

2. Introduction of provisions into local spatial development plans concerning concentration of housing development in existing settlement centres, exclusion of indicated areas from development and, in the case of construction or renovation of buildings, use of solutions proposed in the regional architecture pattern developed specially for the region.

3. Implementation and enhancement of ecological principles of forestry, enrichment the biological diversity and enhancement stability of forest ecosystems, increasing species and age diversity of tree stands, and providing variation to borderlines of forests and thickets.

4. Inhibition of forest succession and prevention of afforestation of valuable natural non-forest habitats (eg peatbogs, heathlands, psammophytic grasslands).

5. Improvement of conditions in hydrogenic habitats by increasing local retention rates; prevention of habitat eutrophication; elimination or damming of some drainage ditches; stabilisation of the water level in river valleys; renaturalisation of water courses and local reconstruction of backwater areas; conservation and design of a varied structure of rush communities and nympheids; increasing the share of coniferous trees (which contribute to de-eutrophication of habitats) in lake catchments; mechanical removal of excess biomass of expansive aquatic plants (in particular Stratiotes aloides); elimination or limitation of the recreational use of lakes and ponds with natural values, imposing limits on fishing and the number of fish caught in water reservoirs with natural values.
6. Ecological management of agricultural land by eg diversification of crops, limitation of application of artificial fertilisers and liquid manure, protection of psammophytic grasslands and heathlands against afforestation or agricultural management, etc.

7. Conservation of the most valuable natural, physiognomic, and cultural areas by: inclusion thereof into the borders of Polesie National Park; establishment a new nature reserves or other forms of legal protection; conservation historical sites (eg insurgents campsite from 1863);

8. Limitation of peat and sand excavation, in particular imposing a ban on sand mining in mud turtle breeding sites, and transformation of peat pits into aquatic ecosystems.

9. Improvement of spatial order and landscape aesthetics by eg cultivation of greenery isolation belts along plots with large-scale commercial buildings (farm buildings, warehouses, cold storage plants, etc.), elimination of illegal sand pits and landfills, development of a network of roadside and mid-field tree stands;

10. Compilation of the Catalogue of West Polesie Landscapes with Landscape Interior Cards, application of the catalogue for conservation and design of the Polesie National Park functional area and for landscape education of the public.

Projects for conservation and design of the composition of landscape interiors and gates as well as scenic openings, should vary depending on the physiognomic type of the landscape and local ecological status in accordance with the following recommendations:

- in low-denivelation regions (such as those in the 'West

Polesie' Biosphere Reserve), special protection should be ensured for viewpoints and scenic openings located on hill tops;

- in large-scale open landscapes - uniformly managed and physiognomically monotonous open landscape zones should be made more diverse: water runoff should be halted by creation of local water pits and backwater reservoirs; small, mild hills should be created with groups of trees (preferably Quercus robur and Pinus silvestris) and shrubs (such landscape forms surrounded with vast bogs are described in literature to be particularly characteristic for the landscapes in Polesie at the beginning of the 20th century (Kułak and Chmielewski, 2010); scenic openings should be created along water courses; the largest zones of monocultural landscapes should be transformed into territorial complexes of open, inlaid, and mosaic landscapes;

- in fenced landscapes - hedgerow networks should be maintained in agricultural areas; in landscape interiors undergoing renaturalisation, linear hedgerows should be transformed into zones of broad mosaic or labyrinthine ecotones; 
- in inlaid landscapes - exposition of physiognomically attractive landscape inlays should be emphasised, their surroundings should be protected against management that would be detrimental to nature and landscape aesthetics;

- in mosaic landscapes - mild labyrinthine and terrace ecotones should be preferred; linear ecotones should be enriched;

- in labyrinthine and perforated landscapes - succession of scrub and forest communities in valuable areas of nonforest ecosystems should be limited;

- in covered landscapes - in forests: species and age diversity of tree stands and undergrowth (shrub and groundcover layer) should be increased, backwater reservoirs should be restored; in villages: the traditional spatial layout of settlements should be preserved, buildings with features of regional architecture should be maintained, the use of the regional architecture pattern in newly constructed utility and recreational buildings should be promoted; regional features of household gardens should be maintained, traditional cultivars of ornamental plants and fruit tree should be recommended

Details of project solutions for individual landscape interiors should be developed with reference to specific local circumstances.

\section{DISCUSSION}

The paper presents the results of application of an author-designed method of analysing and mapping of physiognomic composition of the agro-forestry landscape in the central part of the West Polesie Biosphere Reserve. In recent decades, there has been increasing interest in issues concerning non-commercial functions of forests, as well as agricultural areas, including assessment and design of landscape composition with a significant role of landscape interiors and gates. The interest is largely a result of growing social expectations of the quality of landscape as the human living environment (Nijnik and Mather, 2008; Sevenant and Androp, 2009). The author-designed method of analysing and mapping of the physiognomic landscape composition is our response to the challenges formulated by The Common Agricultural Policy after 2013 (2013) and the European Landscape Convention (2000), explained and discussed among others by Prieur et al. (2006). The proposed system of classification of the physiognomic landscape types, landscape interior walls, as well as the structure and dynamics of landscape ecotones proved useful in mapping the physiognomic landscape structure. Such systems are also an important element of the classification of ecological boundaries described by Strayer et al. (2003). The maps presented in Figs 2-4 represent the first mapping of the physiognomic landscape structure. Together with studies of panoramic compositions of landscape interiors (Fig. 5), the maps can be helpful in development of nature conservation plans for national parks or Natura 2000 sites, as well as for management of forest ecosystems. The necessity of developing methods and techniques for such analyses and design has been emphasised since the end of the 20th century (Kuiper, 1998; Hirschnitz-Garbers and Stoll-Kleemann, 2011). The presented results correspond with the growing trend of assessment of the visual landscape character (Tveit et al., 2006) and development of new systems for classification of current landscapes (Mücher et al., 2010).

The concept of compilation of the Landscape Catalogue for a given region as well as the template of the Landscape Interior Card was inspired by the Inventory Cards of Architecture and Building Monuments (Chmielewski, 2012) used since the 50s of the 20th century, as well as by the current recommendations of the European Landscape Convention (2000). Although based on different studies and card templates from those presented in this article, Regional Landscape Catalogues are currently used $e g$ in Catalonia (Nague and Sala, 2006).

\section{CONCLUSIONS}

1. The classification systems proposed for: (a) physiognomic landscape types, (b) landscape interiors walls, and (c) structure and dynamics of landscape ecotones, as well as the presented template of the Landscape Interior Card could play a significant role in development the methodology of landscape studies. They may be useful for investigations in the scope of landscape ecology, landscape architecture, spatial composition analysis, and landscape design.

2. The presented analysis of the composition of landscape interiors in the central part of the West Polesie Biosphere Reserve has shown that the analysed region is characterised by high diversity of landscape texture and presence of numerous interiors as well as landscape openings and gates with varied physiognomy. In the area of 31714 ha, 7 physiognomic landscape types, 230 landscape interiors, 11 zones of open landscape, and 112 patches of dense land cover were identified. Detailed analyses of the composition of the selected landscape interiors have demonstrated that broad, mild gradient and labyrinthine ecotones characterised by high dynamics of succession processes are dominant (over 70\%) in the Polesie National Park. The area outside the National Park is dominated by linear ecotones with anthropologically stabilised structure; however, the share of broad ecotones with gradient or labyrinthine structure is substantial, ie ca. $40 \%$. The analysed region can serve as a good example of proper design of physiognomic landscape structure.

3. The landscape studies facilitated formulation of guidelines on landscape conservation and design as well as a set of rules of conservation and design of the composition of individual landscape interiors and gates in this part of the 'West Polesie' Biosphere Reserve. The guidelines and rules should constitute a substantive guide for upgrading the values of the physiognomic landscape composition in this region. 


\section{ACKNOWLEDGMENTS}

The authors are grateful to the Polesie National Park Authority in Urszulin (Poland) and the National Foundation for Environmental Protection in Warsaw, for their consent to use of fragments (prepared by our authors team) of the Nature Conservation Plan for the Polesie National Park (Weigle, 2014), as part of source materials in writing this article.

Conflict of interest: The Authors do not declare conflict of interest.

\section{REFERENCES}

Bell S., 2001. Landscape pattern, perception and visualisation in the visual management of forests. Landscape Urban Planning, 54, 201-211.

Bell S., 2012. Landscape: Pattern, Perception and Process. Routledge Press; Taylor Francis Group, London and New York, UK and USA, 64-101, 182-242.

Biogeographic Regions in Europe, 2015. www.eea.europa.eu/ data-and-maps/figures

Bogdanowski J., 1976. Composition and planning in landscape architecture (in Polish). Ossoliński National Institute, Publishing House PAN Press, Wrocław-WarszawaKraków- Gdańsk, Poland, 60-67.

Bowman D., Walsh A., and Milne D.J., 2001. Forest expansion and grassland contraction within a Eucalyptus savanna matrix between 1941 and 1994 at Litchfield National Park in the Australian monsoon tropics. Global Ecology Biogeography, 10, 535-548.

Chmielewski T.J., 2005. General characteristics of the West Polesie Biosphere Reserve. In: West Polesie Biosphere Reserve: values, functioning and perspectives of development. Monograph of the region (Ed. T.J. Chmielewski) (in Polish); Polesie National Park and Voivode of Lublin Press, Lublin-Urszulin, Poland.

Chmielewski T.J., 2006. Basic landscape units of Polesie National Park and rules for the management of their resources (in Polish). Problems of Landscape Ecology. Polish Association of Landscape Ecology, Institute of Geography Pomeranian Academy in Słupsk, Poland, 15, 139-154.

Chmielewski T.J. (Ed.), 2009. Ecology of hydrogenic landscapes of the West Polesie Biosphere Reserve (in Polish). University of Life Sciences in Lublin, Poland, 47-70, 253-266.

Chmielewski T.J., 2012. Landscape systems: structure, functionning, planning (in Polish). State Scientific Publishing PWN Press, Warszawa, Poland, 130-145, 303-334.

Chmielewski T.J. and Kulak A., 2014. Physiognomic structure of the landscape. In: Structure of Natura Environment and Landscape Physiognomy (in Polish) (Eds W. Ziaja and M. Jodłowski). Jagiellonian University, Institute of Geography and Spatial Management Press, Kraków, Poland.

Chmielewski T.J., Sowińska-Świerkosz B., Kulak A., and Chmielewski Sz., 2014. Landscapes of the Roztocze region: natural and cultural heritage (in Polish). Uniwersity of Life Sciences Lublin Press, Poland, 48-82.

Clements F.E., 1905. Research Methods in Ecology. University of Nevada Press, Lincoln, USA.
Coop J.D. and Givnish T.J., 2008. Constraints on tree seedling establishment in montane grasslands of the Valles Caldera, New Mexico. Ecology, 89, 1101-1111.

Eriksson L., Nordlund A.M., Olsson O., and Westin K., 2012. Recreation in different forest settings: a scene preference study. Forests, 3, 923-943.

European Landscape Convention. Florence, Italy, 20 October 2000. www.coe.int/europeanlandscapeconvention

European Union Biodiversity Strategy, 2011. http://ec.europa.eu/ environment/nature/info/pubs/docs/brochures/2020\%20 Biod\%20brochure\%20final\%20lowres.pdf

Ewers R.M. and Didham R.K., 2006. Continuous response functions for quantifying the strength of edge effects. J. Appl. Ecol., 43, 527-536.

Fernandez C., Acosta F.J., Abella G., Lopez F., and Daz M., 2002. Complex edge effect fields as additive processes in patches of ecological systems. Ecol. Modell., 149, 273-283.

Forman R.T.T., 1995. Some general-principles of landscape and regional ecology. Landsc. Ecol., 10, 133-142.

Fortin M.J., Olson R.J., Ferson S., Iverson L., Hunsaker C., Edwards G., Levine D., Butera K., and Klemas V., 2000. Issues related to the detection of boundaries. Landsc. Ecol., 15, 453-466.

Hirschnitz-Garbers M. and Stoll-Kleemann S., 2011. Opportunities and barriers in the implementation of protected area management: a qualitative meta-analysis of case studies from European protected areas. Geographical J., 177, 321-334.

Hoekstra J.M., Boucher T.M., Ricketts T.H., and Roberts C., 2005. Confronting a biome crisis: global disparities of habitat loss and protection. Ecology Letters, 8, 23-29.

Implementation of the Forest Europe Commitments. National and pan-European actions 2011-2015. http://www.foresteurope. org/documentos/ImplementationCommitments2015.pdf

Karjalainen E. and Tyrväinen L., 2002. Visualization in forest landscape preference research: a Finnish perspective. Landscape and Urban Planning, 59, 13-28.

Kohsaka R. and Flitner M., 2004. Exploring forest aesthetics using forestry photo contests: case studies of Japanise and German public preferences. Forest Policy Economics, 6, 289-299.

Kondracki J., 1998. Regional Geography of Poland (in Polish). State Scientific Publishing PWN Press, Warszawa, Poland.

Kuiper J., 1998. Landscape quality based upon diversity, coherence and continuity. Landscape planning at different planning - levels in the River area of The Netherlands. Landscape Urban Planning, 43, 91-104.

Kułak A. and Chmielewski T.J., 2010. Changes in the physiognomy of the landscape of the West Polesie from the middle of the 19th century till the beginning of the 21 st century. In: The Future of Hydrogenic Landscapes in European Biosphere Reserves (Eds T.J. Chmielewski, D. Piasecki). University of Life Sciences in Lublin, Polesie National Park, Polish Academy of Sciences - Branch in Lublin, National UNESCO-MaB Committee of Poland, Lublin, Poland.

Lamb R.J. and Purcell A.T., 1990. Perception of naturalness in landscape and its relationship to vegetation structure. Landscape Urban Planning, 19, 333-352. 
Maarel E. van der., 1990. Ecotones and ecoclines are different. J. Veg. Sci., 1, 135-138.

Motloch J.L., 2001. Introduction to Landscape Design. Wiley Press, Inc., 59-68.

Mücher C.A., Klijn J.A., Wascher D.M., Schaminée J.H.J., 2010. New european landscape classification (LANMAP): a transparent, flexible and user-oriented methodology to distinguish landscapes. Ecological Indicators, 10, 87-103.

Myczkowski Z., 2009. Site identity in the landscape. In: Phenomenon of genius loci (in Polish) (Ed. P. Gutowski). Wilanów Palace Museum Press, Warszawa, Poland, 153-162.

Nague J. and Sala P., 2006. Prototype landscape catalogue, summary: conceptual, methodological and procedural bases for the preparation of the Catalan landscape catalogues. The Landscape Observatory, Olot and Barcelona, Spain, 1-34.

Nijnik M. and Mather A., 2008. Analyzing public preferences concerning woodland development in rural landscapes in Scotland. Landscape Urban Planning, 86, 267-275.

Nijnik M., Zahvoyska L., Nijnik A., and Ode A., 2008. Public evaluation of landscape content and change: several examples from Europe. Land Use Policy, 26, 77-86.

Norman S.P. and Taylor A.H., 2005. Pine forest expansion along a forest-meadow ecotone in northeastern California, USA. Forest Ecology Manag., 215, 51-68.

Patoczka P., 2000. Walls and gates in the landscape (in Polish). Cracow University of Technology Press, Kraków, Poland. Series: Architecture, Monograph No. 268, 33-84.

Prieur M., Luginbuel Y., Zoido Naranio F., De Montmallin B., Pedrolli B., Van Mansvelt J.D., and Dorousseau S., 2006. Landscape and sustainable developmant - challenges of the European Landscape Convention. Monograph, Council of Europe Publishing, Strasbourg, France.

Pullin A.S., 2002. Conservation Biology. Cambridge University Press, Cambridge, UK.

Radwan S. (Ed.), 1999. Nature Conservation Plan for the Polesie National Park; Vol. 1. General findings (in Polish). National Foundation for Environmental Protection; Warsaw, Poland, $1-214$.
Radwan S. (Ed.), 2002. Polesie National Park. A scientific monograph (in Polish). MORPOL, Lublin, Poland, 12-14.

Risser P.R., 1995. The Status of the science examining ccotones - A Dynamic aspect of landscape is the area of steep gradients between more homogeneous vegetation associations. Bioscience, 45(5), 318-325.

Sevenant M. and Antrop M., 2009. Cognitive attributes and aesthetic preferences in assessment and differentiation of landscapes. J. Environmental Manag., 90, 2889-2899.

Strayer D.L., Power M.E., Fagan W.F., Pickett S.T.A., and Belnap J., 2003. A classification of ecological boundaries. Bioscience, 53, 723-729.

The Common Agricultural Policy after 2013; Summary Report. 2013. European Commission; Agriculture and Rural Development. http://ec.europa.eu/agriculture/cap-post2013/debate/report/summary-report_en.pdf

Tveit M., Ode A., and Fry G., 2006. Key concepts in a framework for analysing visual landscape character. Landsc. Res., 31(3), 229-255.

Van Auken O.W., 2000. Shrub invasions of North American semiarid grasslands. Annual Review Ecology Systematics, 31, 197-215.

Weigle A. (Ed.), 2014. Nature Conservation Plan for the Polesie National Park (in Polish). National Foundation for Environmental Protection, Warsaw, Poland, VIII, 1-198.

Weltzin J.E. and McPherson G.R., 2000. Implications of precipitation redistribution for shifts in temperate savanna ecotones. Ecology, 8, 1902-1913.

Yarrow M.M. and Marin V.H., 2007. Toward conceptual cohesiveness: a historical analysis of the theory and utility of ecological boundaries and transition zones. Ecosystems, 10, 462-476.

Zonneveld I.S., 1989. The land unit - A fundamental concept in landscape ecology and its application. Landscape Ecology, $3,67-86$ 